\title{
Effect of low dose gamma irradiation and refrigeration on the chemical and microbial quality of shrimp (Penaeus monodon)
}

\author{
B. MANJANAIK ${ }^{1 *}$ and VeEna ShetTY2 \\ ${ }^{1}$ Department of Fish Processing Technology, College of Fisheries (KVAFSU), MANGALORE (KARNATAKA) INDIA \\ ${ }^{2}$ Department of Microbiology, K.S. Hegde Medical Academy, MANGALORE (KARNATAKA) INDIA \\ Email: : manjanaikb@rediffmail.com
}

*Author for Correspondence

Research chronicle : Received : 06.07.2017; Revised : 12.11.2017; Accepted : 26.11.2017

SUMMARY :

The present investigation is aimed at studying the effect of gamma irradiation (1,3 and $5 \mathrm{kGy})$ and subsequent storage at refrigeration temperature $\left(4^{\circ} \mathrm{C}\right)$ on the chemical, microbial quality and extended shelf-life of shrimp (Penaeus monodon). The total volatile base nitrogen (TVB-N) and trimethyl amine nitrogen values (TMA-N) of the irradiated shrimp samples significantly decreased in comparison with the control (non-irradiated) stored at $4^{\circ} \mathrm{C}$. The thiobarbituric acid values for the irradiated shrimp was significantly lower than of the non-irradiated samples stored at $4^{\circ} \mathrm{C}(\mathrm{p}<0.05)$. The $\mathrm{pH}$ value of the shrimp was affected significantly by both, irradiation dose and storage temperature $(\mathrm{p}<0.05)$. The total microbial load for the non-irradiated shrimp samples was higher than those of irradiated samples at $4^{\circ} \mathrm{C}$ temperature. The results revealed that the combination of low dose gamma irradiation and refrigeration storage resulted in overall reductions of microbial loads and stabilized the biochemical characteristics of shrimp.

KEY WORDS : Gamma irradiation, Refrigeration storage, TBARS, TMA-N, P. monodon

How to cite this paper : Manjanaik, B. and Shetty, Veena (2017). Effect of low dose gamma irradiation and refrigeration on the chemical and microbial quality of shrimp (Penaeus monodon). Internat. J. Proc. \& Post Harvest Technol., 8 (2) : 131-138. DOI: 10.15740/HAS/IJPPHT/8.2/131-138. 